\title{
Veligers from different populations of sea scallop Placopecten magellanicus have different vertical migration patterns
}

\author{
Joan L. Manuel ${ }^{1, *}$, Scott M. Gallager ${ }^{2}$, Christopher M. Pearce $^{3}$, \\ Darlene A. Manning ${ }^{1}$, Ronald K. O'Dor ${ }^{1}$ \\ ${ }^{1}$ Biology Department, Dalhousie University, Halifax, Nova Scotia, Canada B3H 4J1 \\ ${ }^{2}$ Woods Hole Oceanographic Institute, Woods Hole, Massachusetts 02543, USA \\ ${ }^{3}$ GIROQ, Départment de Biologie, Université Laval, Sainte-Foy, Québec, Canada G1K 7P4
}

\begin{abstract}
Veligers spawned by adults collected from 3 different populations (Georges Bank, Passamaquoddy Bay and Mahone Bay, all on the northeastern coast of North America) of giant scallops Placopecten magellanicus were maintained for $2 \mathrm{mo}$ in replicated, $9.5 \mathrm{~m}$ deep, polyethylene mesocosms with a $1.5^{\circ} \mathrm{C}$ thermal gradient at mid-depth and a $12 / 12$ photoperiod. The populations came from varied hydrographic regimes that might require veligers to have different vertical migration patterns if they are to be in an appropriate area for settlement when they reach competency. Veligers from all populations were found in shallower depths at night than during the day, developed strong bio-convective cells when numbers were high at the surface and were seldom found below the thermocline until about $21 \mathrm{~d}$ after spawning. Under similar conditions, veligers from the 3 populations exhibited significantly different vertical migration patterns and depth distributions. These patterns of vertical distribution are unlikely to be due to differences in buoyancy, growth rate, food density, settlement preference or mesocosm effect, and they differ substantially from patterns of mussel veligers raised according to the same protocol. Such differences may reflect selection for different behaviors in different populations, arguing for an active and genetically controlled component to vertical movements of scallop veligers. The observed patterns of vertical distribution could produce marked differences in horizontal transport in the various physical regimes; increased self-recruitment seems the most likely explanation for the intense selection required to fix such behavior in populations.
\end{abstract}

KEY WORDS: Scallops - Recruitment $\cdot$ Retention · Predator avoidance $\cdot$ Tidal phase $\cdot$ Moon rise

\section{INTRODUCTION}

Vertical migration is a common phenomenon in the world's oceans. Organisms representing all marine and freshwater phyla have been found to migrate vertically (Huntley 1985). Many hypotheses have been proposed to explain the advantages of vertical migration. Most have tried to explain why organisms leave the more productive surface zone (presumably sacrificing the amount of food obtained) to migrate to less productive, often cooler, waters at depth. Recently, there has been substantial support for predator avoidance

•E-mail: manuel@is2.dal.ca causing diel vertical migration in crustacean holoplankton, and less for bio-energetic savings suggested by McLaren (1963) and Enright (1977) (Lampert 1993). However, many other hypotheses have been presented, such as locating phytoplankton distributed at different depths or in patches (Angel 1985), avoidance of UV light (Siebeck 1978, Damkaer 1982), and vertical migration to effect horizontal transport (Hardy \& Gunther 1935). Enright \& Hamner (1967) showed that even the physiology underlying endogenous rhythms is by no means uniform, so vertical migration behavior may have evolved several times, for a variety of purposes, and there are likely many ultimate causes of this behavior, with organisms benefiting from more than 1 at the same time. 
Vertical migration for the purpose of horizontal transport was first proposed by Hardy \& Gunther (1935), who suggested that oceanic plankton, too small to make effective horizontal migrations under their own power, might migrate vertically to allow currents to carry them horizontally. In estuaries Rogers' (1940) hypothesis that vertical migration is a means of preventing organisms washing out of estuaries has been widely substantiated (Sinclair 1988). Even in bays where stratification is weak, shear created by bottom friction can affect horizontal transport, and vertical migration has been shown to be used by resident (but not by non-resident) species to mitigate washout (Kimmerer \& McKinnon 1987). Near reefs and oceanic islands, behavior is recognized as crucial for retention because it is obvious that without a retention mechanism, organisms would flush seaward. In other words, where physical discontinuities can be clearly visualized, evidence is substantial that behavior of the organism aids in retention in a suitable habitat (Sinclair 1988)

Organisms with long pelagic larval stages have very real dispersal problems on off-shore banks such as Georges. In the open ocean, currents are virtually ubiquitous, and any larva that acts as a passive particle will be carried some distance from spawning beds. The problem is greater for benthic invertebrates with limited mobility (where net currents might cause the population to drift downstream with each generation) than for mobile organisms such as fish (that can swim upstream as adults). In order for a benthic population to persist, either larvae must be supplied from elsewhere 'elsewhere' then being faced with the same problem) or the larva must have some strategy to return it to the parental population (such as making a full circuit on an oceanic gyre). This problem is the inverse of that faced by mobile terrestrial forms such as mice. On land, young must expend energy to move away from parents or face increased competition from relatives. In marine systems, the pelagic young of a benthic invertebrate must expend energy to remain in the same reproductive unit as its relatives, if the population is to persist. Thus on land, staying in place is the default, whereas in marine systems, dispersal and washout are defaults. Sinclair (1988) argued convincingly that variability in retention of larval stages in aggregations is an important factor in the year-to-year variability of recruitment in species with pelagic larval stages. He postulated that fish like herring spawn in areas where stratification provides differences in horizontal currents that can be used by vertically migrating larvae to provide horizontal transport, and correlated spawning grounds with the stratification parameter. The number of populations in a species, and the number of individuals in each of those popula- tions, then, is the result of the number and size of persistent oceanographic features that are, in combination with vertical migrations of the larvae, capable of resulting in the aggregation and/or retention of larvae. There is selection for the ability of any individual to continue to be a member of a spatially defined population (Sinclair 1988). Scheltema (1986) also proposed that there might be selection for different behavior in different populations. He suggested that, given the importance of vertical movement for retention in estuaries, oyster Crassostrea virginica and clam Mya arenaria veligers might exhibit different behavior in different types of estuaries.

The sea scallop Placopecten magellanicus consists of a number of partially isolated populations which exchange individuals frequently enough to prevent accumulation of large differences at neutral genetic loci (Beaumont \& Zouros 1991). This is consistent with a hypothesis of mainly self-recruiting sub-populations, and the relatively sedentary nature of the adults makes the retention or return of veligers to adult spawning beds imperative. Two other scallop species, Chlamys islandica (Fevolden 1989) and Aequipecten opercularis (Lewis \& Thorpe 1994), both show genetic evidence of self-recruitment to adult beds. Bay scallop Argopecten irradians veligers are retained in densest concentrations over adult beds, despite tidal currents (Ambrose et al. 1992). Thus evidence is accumulating that scallop beds are mainly self-recruiting, and it is reasonable to suggest that veligers of scallops may have evolved behavior that assists in either retention over or return to adult beds.

Since Placopecten magellanicus beds exist where there are considerable differences in larval habitat in terms of horizontal transport, and show great variability in recruitment historically (Orensanz et al. 1991), this species is an ideal subject for testing both Sinclair's (1988) and Scheltema's (1986) hypotheses. Differences in vertical migration patterns of veligers from different populations would suggest that behavior had been selectively modified by different hydrographies and thus that retention is essential for survival. If larval swimming were too weak to affect vertical distribution, or if larval distribution in the water column did not affect survival, there would be no selection for different behaviors. Since neutral genetic sites show little difference among populations, larval behavior is also unlikely to differ by chance. Even if behaviors improve food location or predator avoidance, such behaviors would not become fixed when the individuals are lost to the breeding population by transport on prevailing currents. Only a small improvement in retention in an area where washout is a real danger is required to confer considerable selective advantage, both immediate (in terms of producing more progeny in the next gen- 
eration) and long term (by allowing selection for characters specific to that location).

Our experiment was designed to address the hypothesis that genetically controlled larval behavior could vary among self-recruiting sub-populations of giant scallops, and that such genetic variability would be produced if horizontal transport due to vertical migration were significantly affecting larval retention and thus larval survival

\section{Mesocosms: intermediate in scale and able to look both ways}

The tower tank of the Aquatron facility at Dalhousie University (Halifax, Nova Scotia, Canada) provides an opportunity to examine the behavior of microscopic organisms at microscopic ( $\mathrm{mm}$ to $\mathrm{cm}$ ) scales in a fine scale $(10 \mathrm{~m})$ environment. Here we can create gradients or discontinuities in salinity, temperature and/or food; control and measure light levels; remove horizontal currents or create artificial levels of turbulence or convective currents in a large cylindrical mesocosm $10.5 \mathrm{~m}$ deep and $3.7 \mathrm{~m}$ in diameter (Balch et al. 1978). The excellent survival of organisms that is typical of mesocosms (Gamble \& Davies 1982) enables repeated sampling of the same cohort, to investigate ontogeny of the observed behaviors. The intermediate scale of such controlled experiments provides insight into both the proximate and ultimate causes, as well as the ultimate ecological significance, of larval behavior.

\section{Three populations with different larval habitats}

The first step in testing this hypothesis is to examine behavior of veligers from different oceanographic regimes. We recognise that areas with different hydrographic properties also differ in other qualities (e.g. light penetration, food concentration, predator population) that may affect vertical migration, but if larval behavior does differ among populations with even limited genetic exchange, strong selective pressure for such differences is indicated. Even if horizontal transport were not the primary selection mechanism for such differences, differences in horizontal movement would still be the result (Hill 1991). For our experiments, we chose animals from 3 populations of scallops that live under different hydrographic conditions.

Georges Bank (Fig. 1) is a large off-shore bank situated on the boundary between Canada and the USA. The bank is typified by a large, well-known, mean residual clockwise gyre with a recirculation time (about 56 d) near its annual average residence time of
54 d (Flagg 1987, Lynch \& Namie 1993). Variations in current suggest that in summer, when the gyre is at its strongest, residence time exceeds recirculation time, while in winter residence time tends to be about half and recirculation time about double the summer values (Loder et al. 1988). It is thought that this gyre helps to retain larvae of fish on the bank (Bumpus 1976). The currents around Georges Bank are strongly influenced by tides, causing peak cross-bank displacements at a depth of $19 \mathrm{~m}$ ) of $5 \mathrm{~km}$ in $12 \mathrm{~h}$, with a net residual displacement of $1.7 \mathrm{~km} \mathrm{~d}^{-1}$. Adult beds of scallops are located in a ring that circumscribes the bank in the vicinity of frontal zones between vertically well-mixed and weakly stratified waters (Tremblay 1991), and $80 \%$ of the adult scallop population is on the northeast edge and northeast peak of Georges Bank. The remarkably similar distribution of veligers of very different size classes (and thus presumably of different ages, since there is no evidence of food limitation; Tremblay 1991) suggests that veligers are retained above this dense area despite a persistent gyre, and contrary to predictions of complicated models of passive drift on Georges Bank (Tremblay et al. 1994). Peak densities of veligers on Georges Bank are 500 to $2000 \mathrm{~m}^{-3}$ (Tremblay 1991). Although autumn spawning had previously been assumed to be the sole spawning period for this population, a recent study reveals that in some years there is a more protracted and temporally erratic spawn in the spring in addition to the synchronized autumn spawn (Dibacco et al. 1995).

Passamaquoddy Bay (Fig. 1) is a macrotidal $18.3 \mathrm{~m}$ maximum) estuary in the Bay of Fundy (Canada) with a flushing time of $15 \mathrm{~d}$ (Trites \& Garrett 1983). Adult beds are near the mouth of this long, narrow bay, whereas veligers are most abundant in the northeast bay, with maximum densities of 10000 veligers $\mathrm{m}^{-2}$. This part of the bay tends to be weakly stratified at about $8 \mathrm{~m}$ depth (Robinson et al. 1992). It appears that veligers are transported by net flow in the surface waters up into the northeast bay of the estuary, and as yet, no explanation of how they return to the parental beds has been published. However, the juvenile scallops in this population are more active and willing to swim than those of other populations (J. L. Manuel pers. obs.), and for that reason have been used for studies of the hydrodynamics of swimming (Manuel \& Dadswell 1990, 1993).

Mahone Bay (Nova Scotia, Canada; Fig. 1) is a relatively open, but silled, estuary with a small tidal range $(2 \mathrm{~m})$, strong stratification, and high temperatures and productivity during the summer and autumn when scallop veligers are present in the greatest numbers after the primary spawn. In some years, there is an additional spring spawning (Dadswell \& Parsons 1992). The bay is subject to complete flushing by storm winds 


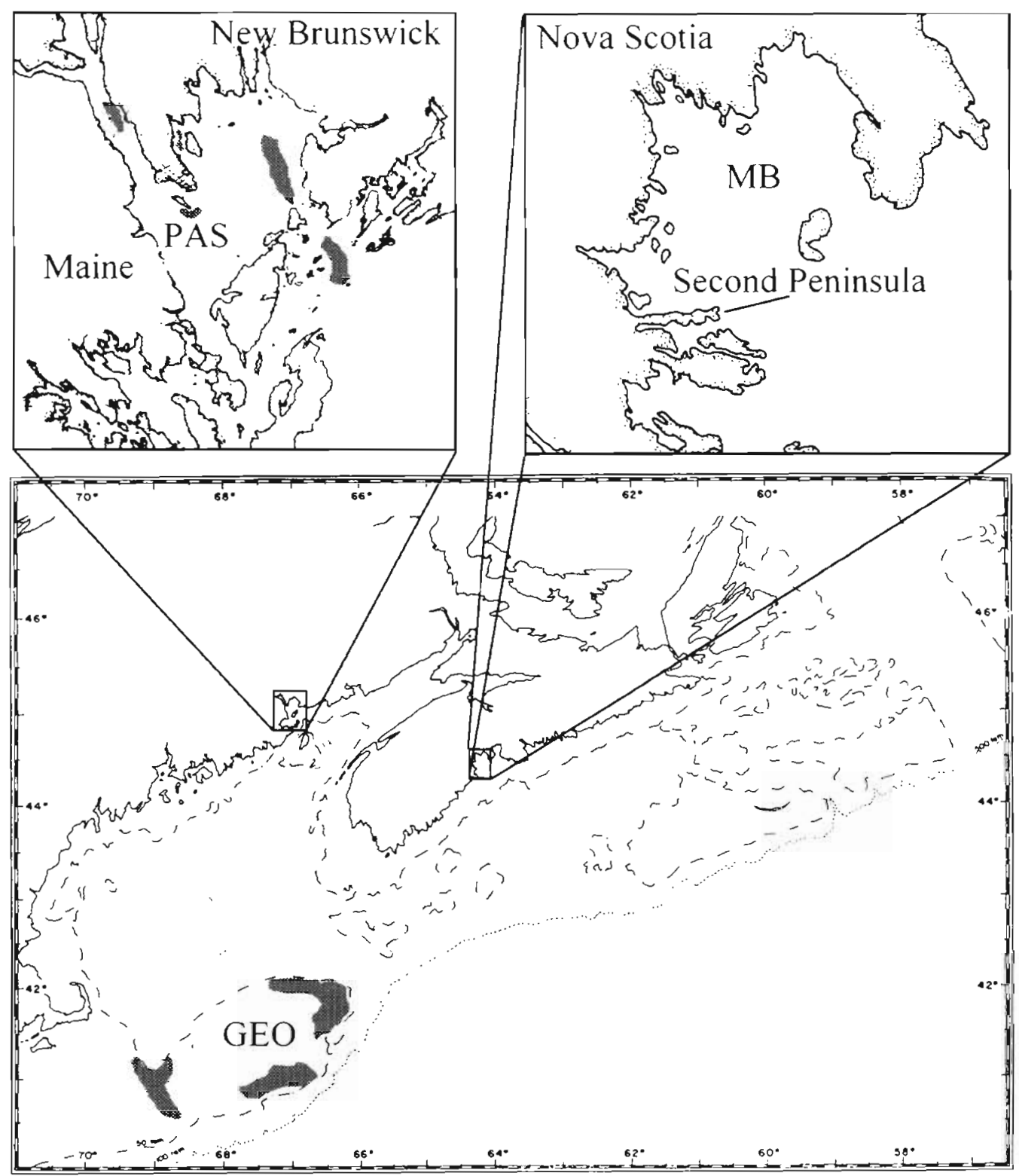

Fig. 1 Map of the region (northeast coast of North America) showing populations of scallops used to produce veligers for the experiment. PAS: Passamaquaddy Bay; MB: Mahone Bay; GEO: Georges Bank. Hatched regions indicate major scallop beds. In Mahone Bay, major beds have hıstorically been on the Second Peninsula side of the bay

from the south, which may significantly affect larval recruitment (Dadswell 1993). Although undocumented, the bay contains a weak counter-clockwise circulation pattern (M. Dadswell pers. comm.) similar to that seen in adjoining St. Margaret's Bay (Din et al. 1970). In the past, the Mahone Bay population supported a strong commercial fishery, which subsequently collapsed, presumably due to overfishing. Presently and historically, the densest aggregations of adult beds are on the western side of the bay, near Second Peninsula.

\section{METHODS AND MATERIALS}

Tower tank and mesocosms. Traditionally, mesocosm studies have been hampered by a reluctance to remove too many animals (which leads to low numbers and a loss of statistical robustness), a suspicion that zooplankton avoid capture because of the shear created by pump sampling, a lack of replication and control in experiments, and contamination by other species (Balch et al. 1978). To deal with control and replication in experiments, we created narrow, deep 
$(0.6 \times 9.5 \mathrm{~m})$ mesocosms of 6 mil polyethylene tubing, suspended at the surface with styrofoam flotation collars (Fig. 2). Each mesocosm was filled with about $2.54 \mathrm{~m}^{3}$ of $1 \mu \mathrm{m}$ filtered sea water. Because survival and growth have been shown to be excellent in such containers in previous experiments (Gallager et al. 1996), there was no need to change water in the mesocosms during the experiment. Thus we were able to avoid the stress and interference with behavior that must accompany passing veligers over a screen. Three replicate mesocosms were used for each treatment. In the main tower tank, which essentially functioned as a water bath, we established a slight thermocline $\left(1.5^{\circ} \mathrm{C}\right)$ by circulating chilled sea water through a titanium ring around the outer edge of the tank at a depth of $4.5 \mathrm{~m}$, and hot water through a PVC ring located $0.5 \mathrm{~m}$ above that (Fig. 2). A $12 / 12$ photoperiod was established with an overhead array of three $1000 \mathrm{~W}$. phosphor-coated, metal-halide lamps. Transitions between light and dark were timed to last about $1 / 2$ h by dephasing overhead light banks and the slow warm-up time for these lights. To simplify sampling logistics, lights turned on at 04:00 h and off at 16:00 h.

Spawning and larval treatment. To reduce differential maternal effects, adult scallops from the 3 populations were maintained at an aquaculture site located at

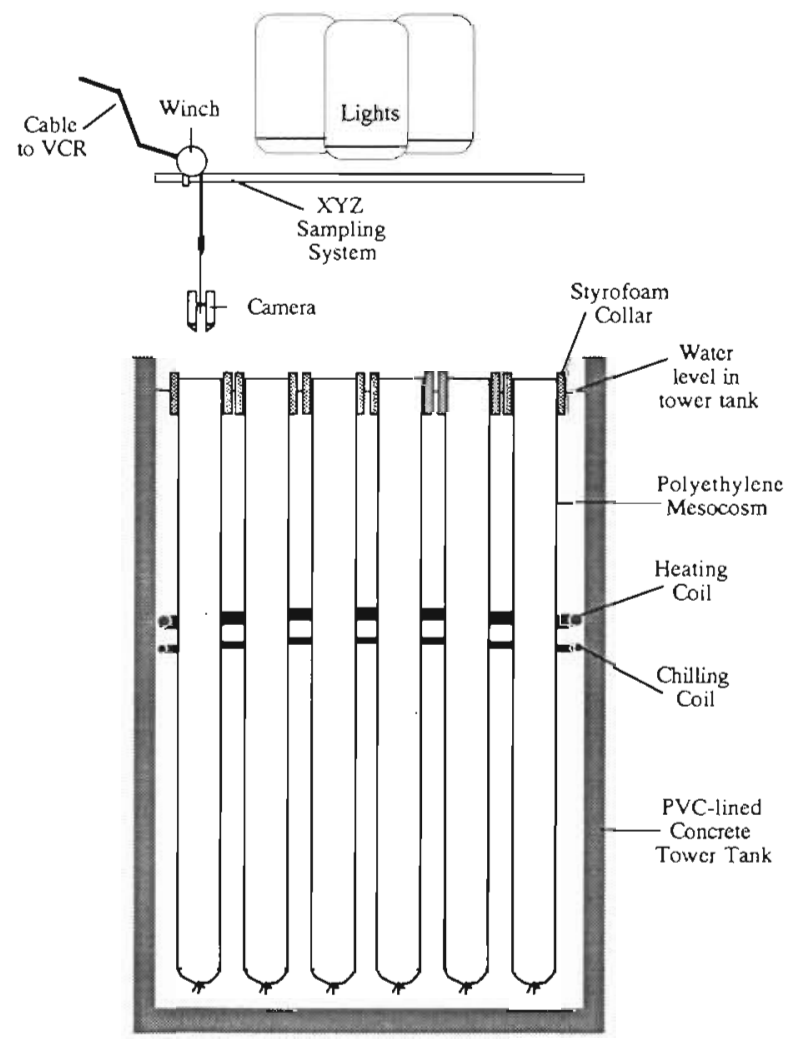

Fig. 2. Side view of the experimental set up in the tower tank, mesocosms drawn to scale
Mahone Bay for a minimum of 1 yr prior to spawning Ripe scallops were retrieved from the site and induced to spawn on the same day (in $0.2 \mu \mathrm{m}$ filtered sea water) by thermal stimulation and agitation of the water with a submersible pump. As many scallops as was practical [6 males and 7 females from Passamaquoddy Bay (PAS): 7 males and 7 females from Georges Bank $(\mathrm{GEO}) ; 6$ males and 6 females from Mahone Bay (MB)] were used as parents to best represent populations and reduce individual effects. The eggs from all females in a given population were mixed together and fertilized with the mixed spawn of all of the males from that population. Sperm was added until several sperm could be seen around each egg when a sample was examined under a light microscope. Five and one-half hours after fertilization, the embryos were distributed to the surface of three $9 \mathrm{~m}$ deep mesocosms (1 per population) at a density of about $5.0 \times 10^{7}$ embryos per mesocosm. Embryos were held without feeding for $4 \mathrm{~d}$ (until the majority were in D-stage), after which time they were concentrated by passing over a $63 \mu \mathrm{m}$ screen and redistributed among the various treatments at the concentration of 1 veliger per $5 \mathrm{ml}\left(5.4 \times 10^{5}\right.$ veligers per mesocosm) Three replicate mesocosms were used for each population, and the mesocosms were distributed randomly around the outside ring of the tower tank. Enough cultured phytoplankton (Isochrysis galbana: clone TISO) was added to each mesocosm to bring the concentration up to $5.0 \times 10^{3}$ cells $\mathrm{ml}^{-1}$. A multisizer Coulter Counter ${ }^{(\oplus)}$ was used thereafter to monitor particle density and supplementary cultured phytoplankton was added to return to this density whenever it fell below half of that. Supplementary phytoplankton $\left(3.0 \times 10^{3}\right.$ cells $\left.\mathrm{ml}^{-1}\right)$ was added on 4 occasions: at 10 , 14,22 , and $30 \mathrm{~d}$ of age. Phytoplankton was gravity fed into the mesocosms via a vinyl sprinkler hose which had been perforated at $2 \mathrm{~cm}$ intervals along its length and cut to the same length as the depth of the mesocosms. Coulter counts indicated that this resulted in even distribution of food particles, ensuring that patches of food did not affect larval distribution.

Non-invasive sampling. We observed veligers in situ with a submersible video camera similar to that used by Gallager et al. (1996), although this camera did not utilize the crossed polarized lenses described by them. The video camera, equipped with a close-up lens, was enclosed in a water-proof housing with a $25 \mathrm{~W}$ halogen light source (Manuel 1996). Observation at night of dense aggregations of veligers indicated that they did not show any response within several hours to a light source of this size. Field of view was about $3 \times 2.8 \times$ $6 \mathrm{~cm}$. A monitor and a VCR at the surface recorded video images for later analysis with an OPTIMAS ${ }^{\circledR}$ image processing program. The camera was used for near instantaneous vertical profiles of veliger density. 
A remote controlled $\mathrm{XYZ}$ positioner placed the camera over a chosen mesocosm and then lowered it at a steady rate from the top to the bottom of the mesocosm. Vertical profiles of mesocosms were accomplished in less than $1.5 \mathrm{~min}$ for each mesocosm, and a complete set of 22 profiles usually took about $1 \mathrm{~h}$ to complete (additional mesocosms were dedicated to other experiments, to be published elsewhere). Vertical profiles were made near the middle of dark and light cycles when the veligers were $11,19,25,32,35$ and $40 \mathrm{~d}$ of age, and in the middle of the light cycle at age 10 . During a period of $3 \mathrm{~d}$ (ages 28 to $31 \mathrm{~d}$ ) mesocosms were profiled every $2 \mathrm{~h}$.

Invasive sampling. Samples of veligers were routinely removed during the day from each mesocosm for estimates of shell length. A length of hose was used to siphon samples from 3 depths: surface $(0 \mathrm{~m})$, just above the thermocline $(4 \mathrm{~m})$, and below the thermocline $(7 \mathrm{~m})$. The volume of water removed varied with larval density, but no more than 20 l of water was removed for each sample (below the thermocline low numbers made veligers difficult to collect). Veligers were immediately preserved in $1 \%$ formalin buffered with sodium borate, and length (longest measurement, approximately parallel to the umbo) was measured some weeks later using a compound microscope and a calibrated OPTIMAS ${ }^{\circledR}$ image processing program.

Statistics. MANOVAs and ANOVAs were used to test for significant effects of population and age on the length of veligers. In all analyses, length measurements were log transformed because variance increased with mean veliger length. Length distributions were normally distributed within mesocosms, however there were significant differences between mesocosms. Therefore, length measurements were also nested within mesocosms.

Initially (at 11, 19, 25 and $40 \mathrm{~d}$ of age, and from $12: 00 \mathrm{~h}$ at $28 \mathrm{~d}$ to $12: 00 \mathrm{~h}$ at $29 \mathrm{~d}$ ) data were gathered by counting the number of veligers on 250 evenly spaced fields from each profile (1 sample approximately every $3.4 \mathrm{~cm}$ ). This provided non-overlapping coverage, with each sample recording the number of veligers in a volume of $6 \mathrm{~cm}$ length $\times 3 \mathrm{~cm}$ width $\times 2 \mathrm{~cm}$ depth. Statistical analyses of the primary data were performed on the depth center of mass (ZCM) of veligers in each mesocosm:

$$
Z C M=\sum p_{i} z_{1}
$$

where $p_{j}$ is the proportion of the total number of veligers observed in the $i$ th video field, and $z_{l}$ is the mid-depth of the $i$ th video field. $Z C M$ is mathematically equivalent to mean depth. Once we had analysed the initial data, we found that ZCM estimated from smaller data sets of 90 evenly spaced samples per profile produced the same interpretation of the experi- ment as ZCM estimated from data sets of 250 samples from the same profiles. Since the smaller data sets of 90 samples were less time consuming to collect from the tapes ( 8 min vs 50 min per profile), data sets of 90 samples per profile were gathered from the remaining profiles (at 32 and $35 \mathrm{~d}$ of age, and between 14:00 h at $29 \mathrm{~d}$ and $04: 00 \mathrm{~h}$ at $31 \mathrm{~d}$ ). Where these secondary data sets were compared with the initial data, the primary data were reduced to 90 , by selecting from the 250 samples the 90 samples with depths closest to the depths of the smaller sets. This was necessary because on those samples that were heavily skewed towards the surface (primarily night profiles with a large proportion of veligers counted in the first field), the number of subsequent samples in a profile affected the ZCM. This method of reducing from 250 to 90 samples produced ZCMs that were statistically indistinguishable from independently collected data sets of 90 evenly spaced samples per profile. ANOVAs and MANOVAs were used to test for significant effects of population, age and time of day on the ZCM of veligers. Only $Z C M$ was compared, since many night profiles were heavily skewed towards the surface and thus did not have normal distributions. Since variance was reduced at extreme (surface and bottom) $Z C M \mathrm{~s}$, but not in arcsine transformed ZCMs, ZCMs were arcsine transformed to avoid violating the assumption of uniformity of variance in all ANOVAs and MANOVAs (see Sokal \& Rohlf 1981). Post hoc comparisons were generated using the Tukey test.

\section{RESLLTS}

\section{Temperature}

During the first $4 \mathrm{~d}$ of development of the embryos, the temperature in the top half of the tower tank was 15 to $16^{\circ} \mathrm{C}$, and the temperature below the thermocline was 8 to $9^{\circ} \mathrm{C}$. From 4 to $8 \mathrm{~d}$ of age the temperature was somewhat variable, due primarily to the thermal effect of experiments in other mesocosms. However, the variability was spread equally through all treatments and no population was exposed to temperatures that differed substantially from another (Fig 3A). By Day 9 , the temperature in the mesocosms was between 13.2 and $13.5^{\circ} \mathrm{C}$ above the thermocline and between 11.8 and $12.0^{\circ} \mathrm{C}$ below the thermocline. A thermal gradient of about $1.5^{\circ} \mathrm{C}$ occurred between 4 and $5 \mathrm{~m}$ depth. During the next 2 wk (until $28 \mathrm{~d}$ of age) the tank slowly increased in temperature by about $2^{\circ} \mathrm{C}$, with the $1.5^{\circ} \mathrm{C}$ thermocline remaining in the 4 to $5 \mathrm{~m}$ depth range. An increase in flow in the chilling coil after $30 \mathrm{~d}$ of age brought the temperature back down to about 13.5 above and $12.0^{\circ} \mathrm{C}$ below the thermocline by $48 \mathrm{~d}$ 

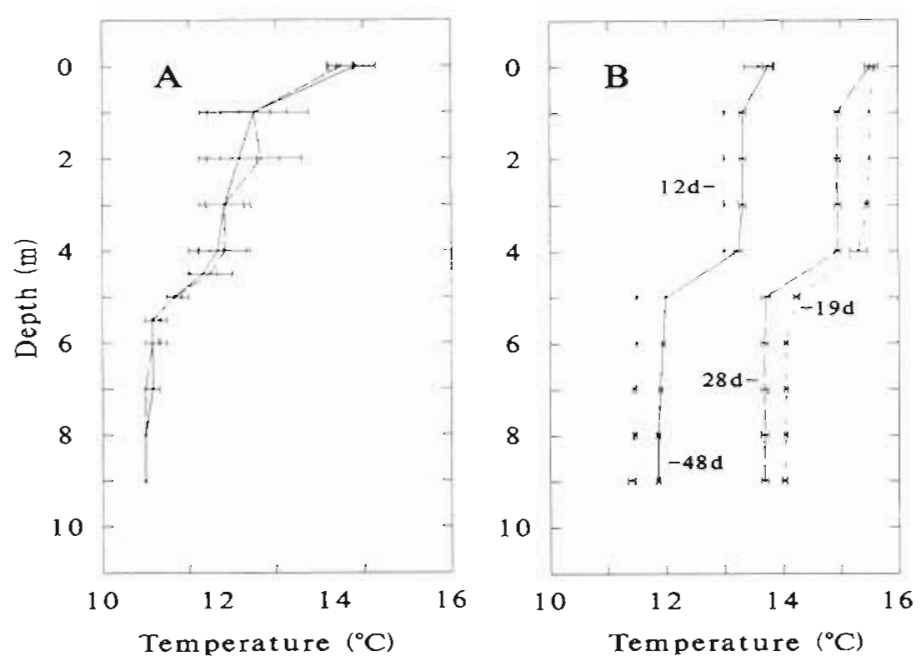

Fig. 3. (A) Temperature in the mesocosms at age $7 \mathrm{~d}$. Solid line: PAS mesocosms; dotted line: MB mesocosms; dashed line: GEO mesocosms. Error bars are standard error of the mean of the 3 replicates for each population. (B) Temperature in the mesocosms from $12 \mathrm{~d}$ until $48 \mathrm{~d}$. Dotted line is age $12 \mathrm{~d}$, small broken line is age $19 \mathrm{~d}$, large broken line is age $28 \mathrm{~d}$, and solid line is age $48 \mathrm{~d}$. Error bars are standard error of the mean of all 9 mesocosms

of age, again maintaining a thermocline of $1.5^{\circ} \mathrm{C}$ between 4 and $5 \mathrm{~m}$ depth (Fig. 3B).

\section{Early larval development}

As soon as the fertilized embryos (about $5.5 \mathrm{~h}$ old) were added to the surface of the mesocosms, they began to sink slowly. Embryos distributed themselves at all depths, but were much denser in the top half of the mesocosm and particularly thick in the region just above the thermocline. Two days after the addition of fertilized eggs, large numbers of swimming veligers were observed at the surface of the mesocosms of the $M B$ and PAS veligers. Although later growth of veligers was similar in all populations (see below) development of GEO embryos through the non-feeding trochophore stage to the shelled, feeding veliger stage was somewhat slower than the other 2 populations, with veligers appearing in great numbers only on the fourth day.

\section{Growth rates}

Growth rate was similar among the 3 populations, at $4.8,4.6$ and $4.3 \mu \mathrm{m} \mathrm{d}^{-1}$ for GEO, MB and PAS veligers repectively. Within each mesocosm, veligers at the surface were significantly smaller than those found at greater depths (Table 1). There was usually a 5 to
$10 \mu \mathrm{m}$ increase in mean veliger length (i.e. the equivalent of 1 to $2 \mathrm{~d}$ growth) between 0 and $4 \mathrm{~m}$, and between 4 and $7 \mathrm{~m}$. This may reflect either more extensive migrations on the part of larger veligers, or that larger veligers were always deeper than smaller ones. Since all of our samples were collected during the day, we could not distinguish between these 2 possibilities. Although inter-mesocosm variations were significant, as in previous experiments (Gallager et al. 1996), there were no significant differences in sizes among the populations at any given date, or during the experiment as a whole (Fig. 4, Table 2A, B). This is an important consideration, since ontogenetic changes in behavior in another population were related to size rather than age (Gallager et al. 1996).

\section{Veliger distribution patterns}

Early distribution patterns (ages 11 and 19 d) show that veligers from all 3 populations shared some common characteristics: (1) except for MB at $19 \mathrm{~d}$, veligers were found in shallower depths at night than during the day, (2) we saw strong bio-convective cells at the surface in the hours after dark, (3)



Fig. 4. Mean veliger shell length in replicate mesocosms by population. Lengths from all 3 depths are included in average. Error bars are standard error of the mean, $\mathrm{n}=3$ for each case. $M: M B ; G: G E O$; P: PAS 
Table 1. Results of MANOVAs on the relationship of the length of veligers to age and depth. Each mesocosm is examined separately: PAS: Passamaquoddy Bay; MB: Mahone Bay; GEO: Georges Bank. Where age $x$ depth was not significant $(p<0.05\}$, it was removed from the analysis. NS: not significant; $M=0.10>p>0.05, \cdot p<0.05, \cdots p<0.01$

\begin{tabular}{|c|c|c|c|c|c|c|}
\hline Population & Replicate & $n$ & $\mathrm{R}^{2}$ & Source & $\mathrm{df}$ & p-value \\
\hline PAS & 1 & 325 & 0.76 & $\begin{array}{l}\text { Depth } \\
\text { Age }\end{array}$ & $\begin{array}{l}2 \\
1\end{array}$ & 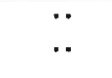 \\
\hline PAS & 2 & 373 & 0.62 & $\begin{array}{c}\text { Depth } \\
\text { Age } \\
\text { Age } \times \text { Depth }\end{array}$ & $\begin{array}{l}2 \\
1 \\
2\end{array}$ & $\dot{.}$ \\
\hline PAS & 3 & 303 & 0.72 & $\begin{array}{c}\text { Depth } \\
\text { Age } \\
\text { Age } \times \text { Depth }\end{array}$ & $\begin{array}{l}2 \\
1 \\
2\end{array}$ & $\begin{array}{l}M \\
\ddot{*} \\
\cdot\end{array}$ \\
\hline $\mathrm{MB}$ & 1 & 275 & 0.79 & $\begin{array}{c}\text { Depth } \\
\text { Age } \\
\text { Age } \times \text { Depth }\end{array}$ & $\begin{array}{l}2 \\
1 \\
2\end{array}$ & $\dot{\cdot}$ \\
\hline $\mathrm{MB}$ & 2 & 286 & 0.75 & $\begin{array}{c}\text { Depth } \\
\text { Age }\end{array}$ & $\begin{array}{l}2 \\
1\end{array}$ & $\ddot{~}$. \\
\hline $\mathrm{MB}$ & 3 & 300 & 0.67 & $\begin{array}{c}\text { Depth } \\
\text { Age } \\
\text { Depth } \times \text { Age }\end{array}$ & $\begin{array}{l}2 \\
1 \\
2\end{array}$ & $\begin{array}{l}\dot{ } \\
\cdots\end{array}$ \\
\hline GEO & 1 & 273 & 0.68 & $\begin{array}{l}\text { Depth } \\
\text { Age }\end{array}$ & $\begin{array}{l}2 \\
1\end{array}$ & .. \\
\hline GEO & 2 & 287 & 0.72 & $\begin{array}{l}\text { Depth } \\
\text { Age }\end{array}$ & $\begin{array}{l}2 \\
1\end{array}$ & $\ddot{~}$ \\
\hline GEO & 3 & 325 & 0.72 & $\begin{array}{l}\text { Depth } \\
\text { Age }\end{array}$ & $\begin{array}{l}2 \\
1\end{array}$ & $\begin{array}{l}\text { NS } \\
\cdots\end{array}$ \\
\hline
\end{tabular}

Table 2A. Results of ANOVAs to test whether length of veligers differed significantly among populations. Each age is treated separately, and because of significant mesocosm effects, length measurements are nested within replicate mesocosms. All depths are included in analysis. Age 4 is taken before the experiment began, when only 1 mesocosm existed per population. Note the low $R^{2}$ value. NS: not significant $_{i}{ }^{\prime} p<0.01$

\begin{tabular}{|ccccc|}
\hline Age (d) & $n$ (mesocosms) & $n$ (veligers) & \multicolumn{1}{c|}{$\mathrm{R}^{2}$} & Significance \\
\hline 4 & 3 & 75 & 0.16 & $\cdots$ \\
11 & 9 & 523 & 0.06 & NS \\
18 & 9 & 618 & 0.12 & NS \\
25 & 9 & 699 & 0.14 & NS \\
32 & 9 & 657 & 0.11 & NS \\
\hline
\end{tabular}

very few veligers were found below the thermocline, and (4) veligers were found in shallower depths at 19 than at $11 \mathrm{~d}$ (Fig. 5, Table 3). We considered whether the last result may have been affected by food density - veligers were fed $2 \mathrm{~d}$ before the profiles on Day 11 , and particle levels were not low enough to require feeding for another $3 \mathrm{~d}$. On the other hand, veligers were fed 5 d before the profiles on Day 19, and food levels were low enough to require feeding the next day. However, a day profile on Day 10 was also shallower than on Day 11, arguing against this interpretation of the data. Whatever the other effects, population
Table 2B. Results of ANOVAs to test whether length of veligers differed significantly among populations. Model includes ages 11 to $32 \mathrm{~d}$, and because of significant mesocosm effects, length measurements are nested within replicate mesocosms. All depths are included in analysis. In all tests, $\mathrm{n}=2747$. NS: not significant; $\cdots p<0.01$ Pop: population of veliger parents

\begin{tabular}{|c|c|c|c|}
\hline Source of variation & Error term & $\mathrm{R}^{2}$ & $\mathrm{p}$ \\
\hline $\begin{array}{l}\text { Pop } \\
\text { Age } \\
\text { Pop } \times \text { Age } \\
\text { Mesocosm }\{\text { Pop }\} \\
\text { Age } \times \text { Mesocosm }\{\text { Pop }\}\end{array}$ & Mesocosm $\{$ Pop $\}$ & 0.70 & NS \\
\hline $\begin{array}{l}\text { Pop } \\
\text { Age } \\
\text { Pop Age }\end{array}$ & Mesocosm $\{$ Pop $\}$ & 0.69 & NS \\
\hline $\begin{array}{l}\text { Mesocosm }\{\text { Pop }\} \\
\text { Pop } \\
\text { Age } \\
\text { Mesocosm }\{\text { Pop }\}\end{array}$ & Mesocosm $\{$ Pop $\}$ & 0.69 & $\begin{array}{l}\text { NS } \\
\cdots\end{array}$ \\
\hline
\end{tabular}

always had a significant effect on $Z C M$, GEO veligers tending to be the deepest, and PAS veligers being the shallowest (Tables $3 \& 4$ )

Sometime between the ages of 19 and $25 \mathrm{~d}$, veligers from $M B$ and $G E O$ began to make excursions below the thermocline during the day. Such excursions may 
Table 3. Mean ZCMs of early and late profiles. Abbreviations as in Table 1

\begin{tabular}{|ccccc|}
\hline $\begin{array}{l}\text { Age } \\
\text { (d) }\end{array}$ & $\begin{array}{c}\text { Days since } \\
\text { feeding }\end{array}$ & Population & $\begin{array}{c}\text { Mean } Z C M(\mathrm{~m}) \\
\text { day profiles }\end{array}$ & $\begin{array}{c}\text { Mean } Z C M(\mathrm{~m}) \\
\text { night profiles }\end{array}$ \\
\hline 10 & 1 & GEO & 262 & \\
10 & 1 & MB & 144 & \\
10 & 1 & PAS & 134 & \\
11 & 2 & GEO & 307 & 233 \\
11 & 2 & MB & 274 & 149 \\
11 & 2 & PAS & 227 & 122 \\
19 & 5 & GEO & 148 & 40 \\
19 & 5 & MB & 65 & 75 \\
19 & 5 & PAS & 68 & 16 \\
40 & 4 & GEO & 385 & 398 \\
40 & 4 & MB & 423 & 271 \\
40 & 4 & PAS & 206 & 173 \\
& & & & \\
\hline
\end{tabular}

GEO veligers descended after midnight, but did not go below the thermocline until after dawn (Fig. 6).

After $31 \mathrm{~d}$, veligers from both $\mathrm{GEO}$ and $\mathrm{MB}$ continued to migrate through the thermocline, but gradually more veligers were seen below the thermocline at night, and the differences between day and night distributions are reduced. By age $35 \mathrm{~d}$ the distribution of veligers in 4 of the mesocosms ( $2 \mathrm{MB}$ and $2 \mathrm{GEO}$ ) had become nearly random, with veligers located throughout the water column both day and night. By $40 \mathrm{~d}$ of age veligers no longer exhibited differences in their day and night distributions and no longer exhibited extreme aggregations and bio-convective cells at the surface at night. It is not known whether the veligers ceased to migrate, or simply lost the synchrony of their migrations. Even at this late date, PAS veligers

have occurred and not been detected in the younger stages, since we profiled only in the middle of the light cycle at 11 and $19 \mathrm{~d}$ of age. However, comparing profiles taken at the same time of day as on previous dates showed that the distribution had changed at the time of day when the earlier profiles were done. Specifically, veligers were found below the thermocline mid-day in GEO and MB mesocosms at ages 25, 28, 29 and $30 \mathrm{~d}$, whereas few were found below the thermocline mid-day at ages 10,11 and 19 d. Samples taken for size analysis indicated that this was approximately the size at which veligers were entering the 'umbo' stage of development. To better quantify the behavior, we recorded profiles every $2 \mathrm{~h}$ for $62 \mathrm{~h}$ starting at $28 \mathrm{~d}$ of age. During this time, veligers from different populations exhibited very different vertical distributions (Fig. 6). Taken as a whole, the differences among populations are extremely significant, with time of day and population together explaining about $90 \%$ of the variation in depth center of mass (Table 4).

For descriptive purposes, we also performed ANOVAs on each of the profile sets individually, to show at what time of day the differences were most significant (Table 5). PAS veligers were always significantly shallower than the others with the exception of $M B$ veligers at 00:00 h. GEO and $M B$ veligers were not distinguishable during daylight hours (04:00 to 16:00 h), but after dark $M B$ veligers tended to be located at shallower depths than GEO veligers, and remained near the surface until dawn. still tended to be found at shallower depths than the other 2 populations (Table 4 ), although day/night differences had disappeared, and some veligers were found below the thermocline (Fig. 7).

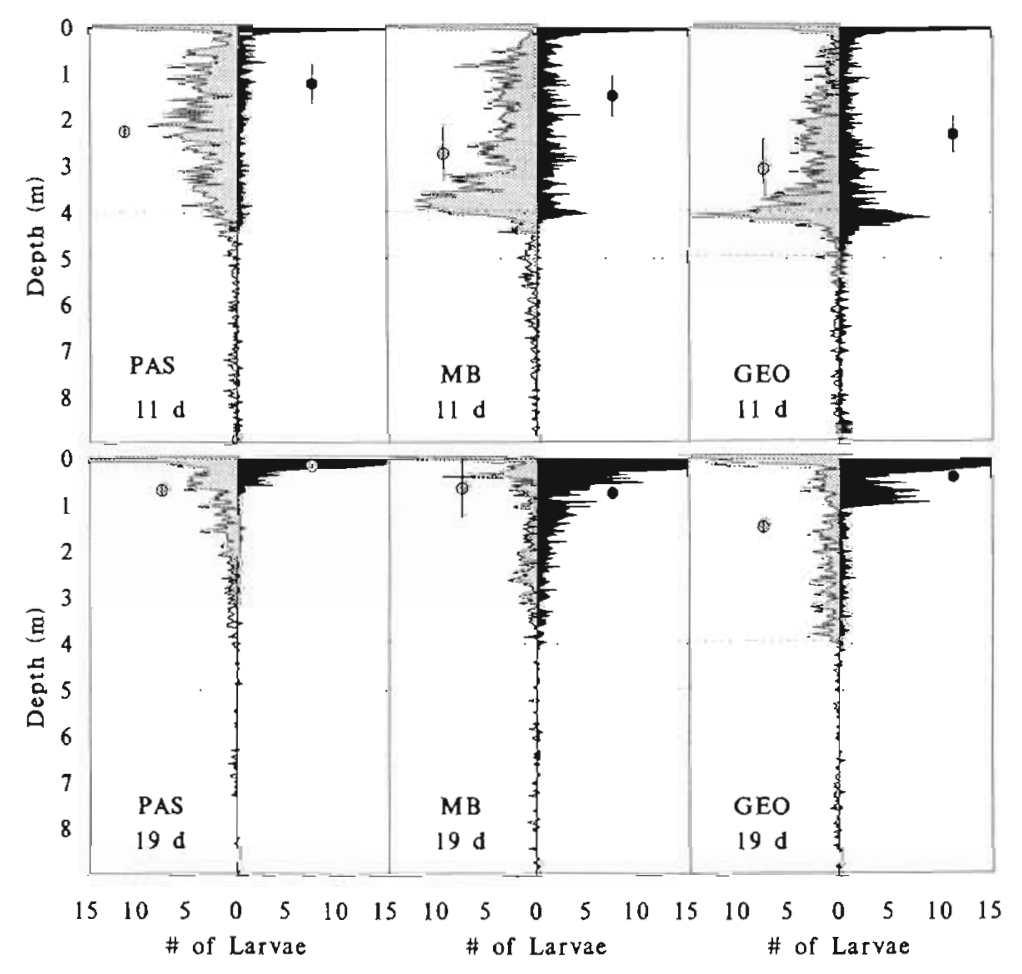

Fig. 5. Vertical distribution of numbers of veligers for each population at 11 and $19 \mathrm{~d}$. Replicate profiles have been averaged and the series smoothed. Day profiles are filled with grey, night profiles are filled with black. Surface distributions that meet the outer limits of the graph actually extend beyond the maximum (15) graphed here. Filled circles are $Z C M$, calculated by averaging $Z C M$ s from 3 replicates. Error bars are standard error of the mean 
Table 4. Results of MANOVAs of the relation of time of day (hour) and population to arcsine transformed $Z C M$. Hour is treated as a category vanable. NS: not significant; $M=0.10>p>0.05, p<0.05, \cdots p<0.01$. Pop: population of veliger parents. Other abbreviations as in Table 1

\begin{tabular}{|c|c|c|c|c|c|c|c|c|}
\hline \multirow{2}{*}{$\begin{array}{l}\text { Data range in days (d) } \\
\text { and time }(\mathrm{h})\end{array}$} & \multirow[t]{2}{*}{$n$} & \multirow[t]{2}{*}{$\mathrm{R}^{2}$} & \multirow{2}{*}{$\begin{array}{l}\text { Source of } \\
\text { variation }\end{array}$} & \multirow[t]{2}{*}{$\mathrm{df}$} & \multirow[t]{2}{*}{$p$} & \multicolumn{3}{|c|}{ Tukey post hoc } \\
\hline & & & & & & $\begin{array}{c}\text { GEO } \\
\text { VS MB }\end{array}$ & $\begin{array}{l}\text { GEO } \\
\text { vs PAS }\end{array}$ & $\begin{array}{c}\text { MB } \\
\text { vs PAS }\end{array}$ \\
\hline \multirow{3}{*}{$\begin{array}{l}10 d+11 d \\
+19 d\end{array}$} & \multirow[t]{3}{*}{40} & \multirow[t]{3}{*}{0.76} & Pop & 2 & $\cdot$ & & & \\
\hline & & & Hour & 4 & $\cdot \cdot$ & & & \\
\hline & & & Pop $\times$ Hour & 8 & NS & & & \\
\hline \multirow{2}{*}{$\begin{array}{l}10 d+11 d \\
+19 d\end{array}$} & \multirow[t]{2}{*}{40} & \multirow[t]{2}{*}{0.70} & Pop & 2 & .. & \multirow[t]{2}{*}{$\cdot$} & \multirow[t]{2}{*}{.. } & \multirow[t]{2}{*}{ NS } \\
\hline & & & Hour & 4 & $\cdot \cdot$ & & & \\
\hline \multirow{3}{*}{$\begin{array}{l}28 \mathrm{~d}, 12: 00 \mathrm{~h} \\
\quad \text { to } \\
29 \mathrm{~d}, 12: 00 \mathrm{~h}\end{array}$} & \multirow{3}{*}{112} & \multirow{3}{*}{0.90} & Pop & 2 & $\cdot \cdot$ & \multirow[t]{6}{*}{$\cdots$} & \multirow{6}{*}{.} & \multirow[t]{6}{*}{. } \\
\hline & & & Hour & 11 & $\cdot \cdot$ & & & \\
\hline & & & Pop $\times$ Hour & 76 & $\cdot \cdot$ & & & \\
\hline \multirow[t]{3}{*}{$35 d+40 d$} & \multirow[t]{3}{*}{36} & \multirow[t]{3}{*}{0.62} & Pop & 2 & $\cdot \cdot$ & & & \\
\hline & & & Hour & 3 & $\mathrm{M}$ & & & \\
\hline & & & Pop $\times$ Hour & 6 & NS & & & \\
\hline \multirow[t]{2}{*}{$35 d+40 d$} & \multirow[t]{2}{*}{36} & \multirow[t]{2}{*}{0.54} & Pop & 2 & $\cdot \cdot$ & & & \\
\hline & & & Hour & 3 & M & & & \\
\hline $35 d+40 d$ & 36 & 0.41 & Pop & 2 & $\cdot \cdot$ & NS & .. & .. \\
\hline
\end{tabular}

Table 5. Results of ANOVAs of the relationship between arcsine transformed ZCM and population, by hour. NS: not significant; $\mathrm{M}=0.10>\mathrm{p}>0.05, \mathrm{p}<0.05, \cdots p<0.01$. Other abbreviations as in Table 1

\begin{tabular}{|c|c|c|c|c|c|c|c|c|}
\hline \multirow{2}{*}{$\begin{array}{l}\text { Age } \\
\text { (d) }\end{array}$} & \multirow{2}{*}{$\begin{array}{l}\text { Time } \\
\text { (h) }\end{array}$} & \multirow[t]{2}{*}{$\mathrm{n}$} & \multirow[t]{2}{*}{$d f$} & \multirow[t]{2}{*}{$p$} & \multirow[t]{2}{*}{$\mathrm{R}^{2}$} & \multicolumn{3}{|c|}{ - Tukey post hoc } \\
\hline & & & & & & GEO vs MB & GEO vs PAS & MB vs PAS \\
\hline 28 & $12: 00$ & 8 & 2 & $\cdot$ & 0.72 & NS & $\cdot$ & $\cdot$ \\
\hline 28 & $14: 00$ & 9 & 2 & $\because$ & 0.87 & NS & $\cdots$ & $\because$ \\
\hline 28 & $16: 00$ & 9 & 2 & $\because$ & 0.81 & NS & $\cdots$ & $\because$ \\
\hline 28 & $18: 00$ & 8 & 2 & $\cdot$ & 0.80 & $M$ & $\because$ & M \\
\hline 28 & $20: 00$ & 9 & 2 & $\cdot$ & 0.79 & $M$ & $\cdots$ & $\cdot$ \\
\hline 28 & $22: 00$ & 9 & 2 & $\cdots$ & 0.94 & $\because$ & $\because$ & $\because$ \\
\hline 29 & $00: 00$ & 9 & 2 & $\cdots$ & 0.92 & $\because$ & $\cdots$ & NS \\
\hline 29 & $02: 00$ & 9 & 2 & $\because$ & 0.88 & $\cdots$ & $\cdots$ & $M$ \\
\hline 29 & $04: 00$ & 9 & 2 & $\cdot$ & 0.61 & NS & $\cdot$ & $\cdot$ \\
\hline 29 & $06: 00$ & 9 & 2 & $\cdots$ & 0.93 & $\mathrm{M}$ & $\cdots$ & $\cdots$ \\
\hline 29 & $08: 00$ & 7 & 2 & $\cdots$ & 0.96 & NS & $\cdots$ & $\because$ \\
\hline 29 & $10: 00$ & 8 & 2 & $\cdot$ & 0.82 & NS & $\cdots$ & $\cdot$ \\
\hline
\end{tabular}

\section{DISCUSSION}

\section{How do our vertical distributions compare with previous studies?}

The light levels in the tower tank (Pearce et al. 1996) are much less than natural light conditions (ranging from 1800 to 7000 lux at the surface) and because the tank is solid and the light is not source collimated, light attenuation in the tower tank is greater than under natural conditions (Collins 1989). All veligers might have moved deeper in the water column if light levels were higher. Thus, the absolute ZCMs in our mesocosms are expected to be somewhat shallower than in the field if the strength of veliger response to light is correlated to light intensity. If, however, veligers respond to changes in light intensities, as do many crustaceans (Forward 1988), then ZCM under our conditions might more closely approximate natural conditions. Mesocosm conditions also lack the mixing effects of winds and tides, which might tend to disperse aggregations and/or carry the veligers deeper or shallower. ZCM of veligers was modified by the presence of a thermocline at $4.5 \mathrm{~m}$, a depth that is appropriate for PAS and $\mathrm{MB}$ but not for GEO veligers. Thus, the ZCMs that we observed are the result of veliger swimming without passive transport by external sources such as winds, large scale currents or tides. Thus differences in 


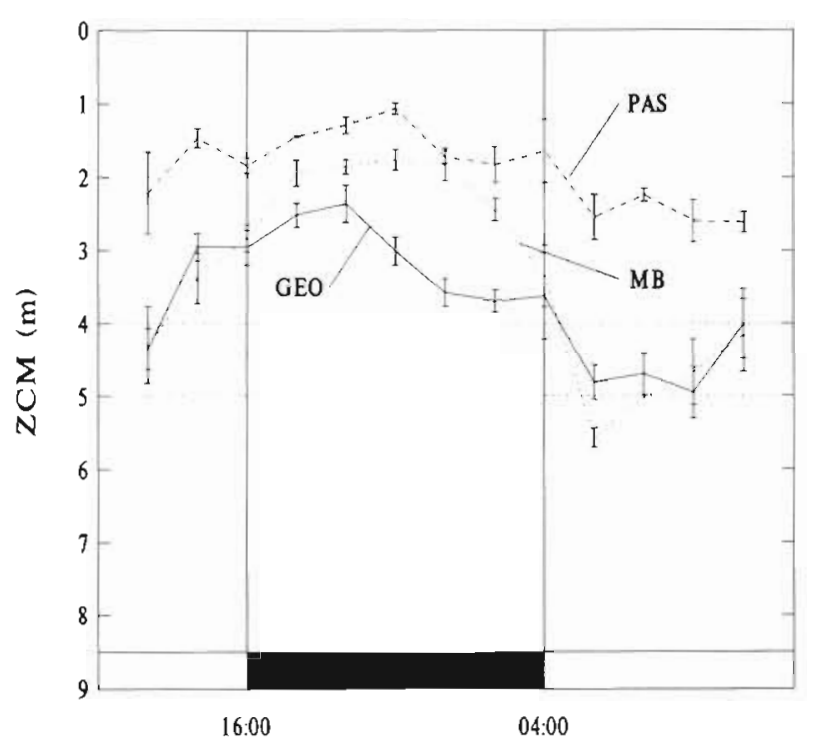

Light/Dark Cycle

Fig. 6. Mean ZCM of replicate mesocosms in the 3 populations, from $12: 00 \mathrm{~h}$ at $28 \mathrm{~d}$ to $12: 00 \mathrm{~h}$ at $29 \mathrm{~d}$. Error bars are standard error of the mean for the 3 replicates in each population. Clear boxes indicate when lights were on; black boxes indicate darkness

$Z C M$ among populations indicate that veligers have responded differently to the same, relatively realistic, conditions, but do not predict the depth of veligers in the field. The overall pattern is, nonetheless, consistent with a number of previous observations (if not always with the interpretations of those observations).

The intense aggregations near the surface and the daily vertical migrations exhibited by veligers from all 3 populations of Placopecten magellanicus in this study are similar to previously reported behavior exhibited by veligers of P. magellanicus spawned from adults taken from a population in Newfoundland (Canada; Gallager et al. 1996). Laboratory observations of scallop larvae also suggest behavior similar to some of our observations. Pecten maximus larvae swim to the surface as trochophores, tend to be nearer the surface from 4 to $23 \mathrm{~d}$ of age, and after that nearer the bottom (Cragg 1980). Culliney (1974) noted that $P$. magellanicus veligers clustered in the top $1 / 3$ of the container used to rear them until Day 23, and then moved closer to the bottom.

Genetically, Placopecten magellanicus seems to consist of a number of partially isolated, presumably largely self-recruiting populations which exchange individuals frequently enough to prevent accumulation of large genetic differences at neutral genetic loci (Beaumont \& Zouros 1991). Tremblay (1991) suggested that differences in morphology, growth rate and spawning time of $P$. magellanicus indicate that selfrecruitment of major scallop beds is more prevalent than commonly supposed. He proposed that vertical migration of veligers might tend to aid retention of veligers, and found evidence of diel movement in veligers of $P$. magellanicus near Passamaquoddy Bay (Tremblay \& Sinclair 1990b) but none on Georges Bank (Tremblay \& Sinclair 1990a). In those studies, samples were collected using a relatively large pump, and thus probably inadequately sampled the top $0.5 \mathrm{~m}$ of the water column. Both our experiment and a previous experiment with a fourth population (Gallager et al. 1996) suggest that $P$. magellanicus veligers are at times very close to the surface under mesocosm conditions. At Grand Manan (border of Maine and Nova Scotia), slight changes in the $Z C M$ of veligers were concordant with fluctuations in numbers caught (Tremblay \& Sinclair 1990b). Since lower numbers of veligers were associated with shallower depths, and the number of larger veligers (which were spread evenly throughout the water column in our study) did not fluctuate, there is a strong possibility that the migrations performed at that site were actually much greater than the data of Tremblay \& Sinclair (1990b) would indicate, and strong aggregations near the surface may have been missed. Even if there was no systematic error in the sampling, the fact that veligers occurred in substantial patches in an area of strong tidal mixing suggests that active movement tended to aggregate them. On Georges Bank, Tremblay \& Sinclair (1990a) detected changes in vertical distribution

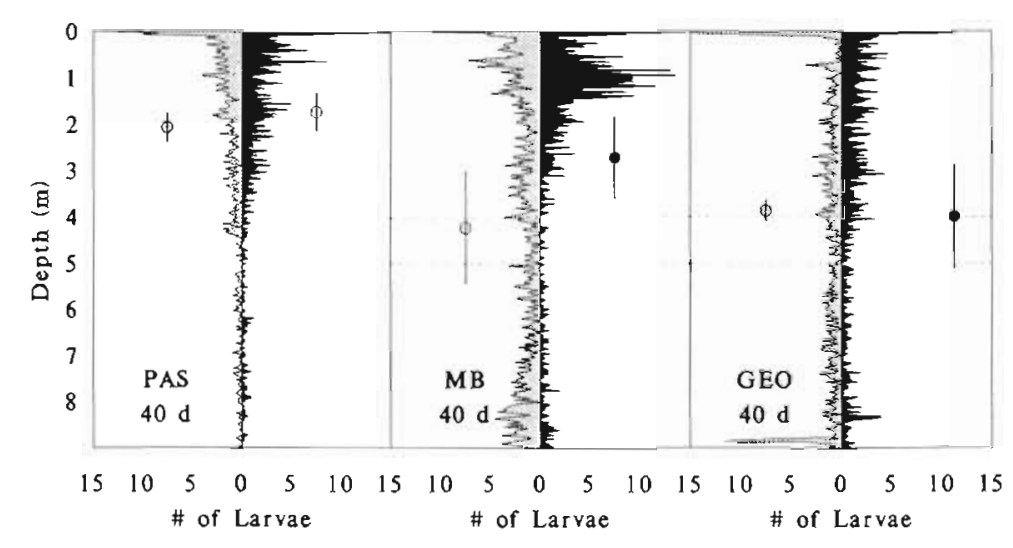

Fig. 7. Vertical distribution of of numbers of veligers for each population at age $40 \mathrm{~d}$. Replicate profiles have been averaged and the series smoothed. Day profiles are filled with grey, and night profiles are filled with black. Surface distributions that meet the outer limits of the graph actually extend beyond the maximum (15) graphed here. Filled circles are $Z C M$, calculated by averaging $Z C M$ s from 3 replicates. Error bars are standard error of the mean 
over time and between areas, although they could not relate those to diurnal migration. Given the low resolution of the sampling (every $10 \mathrm{~m}$ ), and the considerable movement of water masses in the region, it is difficult to conclude that migration had not occurred (see Manuel 1996 for another interpretation of their results).

Veligers from all populations were located at shallower depths on Days 10 and 19 than they were on the Day 11 . This result seems to contradict previously published observations (Gallager et al. 1996) on ontogenetic changes in distribution, which suggested that veligers were found at increased depth at increased size and/or age. It is possible that the level of food present affected vertical distribution, but the shallower depth of veligers in both the mid-day sample at age 10 (1 d after feeding) and Day 19 (5 d after feeding) combined with the deeper distribution on Day 11 ( $2 \mathrm{~d}$ after feeding) shows that either food was not causative, or the relation between food level and vertical distribution is not linear. Thus ontogenetic changes in depth distribution of veligers in this study were complex, and not a simple increase with age or size as reported for a previous study (Gallager et al. 1996). The essential observation for this discussion is that vertical distributions under the same conditions differed among populations on most occasions, suggesting that there has been selection for different vertical migration behavior in different populations.

\section{Hypotheses that do not explain the observed differences among populations}

Vertical migration probably affects many aspects of bivalve veliger survival, but only horizontal transport and possibly predation avoidance are consistent with our observations. Other hypotheses commonly proposed to induce vertical migration in zooplankton are unlikely explanations for vertical migration of Placopecten magellanicus veligers in mesocosms. Neither McLaren's (1963) nor Enright's (1977) model for energy savings from vertical migrations fits our observations. Gallager et al. (1996) showed that veligers from Trinity Bay, Newfoundland were seldom found below the thermocline until they approached competency. The type of energy savings proposed by McLaren (1963) would only be obtained if the veligers consistently moved below the thermocline frequently, since digestion of gut contents in veligers this size is relatively rapid, perhaps as fast as $15 \mathrm{~min}$. Another argument against this interpretation is that veligers' relatively high weight in water requires them to swim almost continuously, and satiation simply results in rejection of captured particles (Gallager 1988), not a cessation of activity. Thus it is unlikely that bivalve veligers save any energy by not feeding. Since Enright's model (1977) is sensitive to energy savings from intermittent feeding, it cannot apply in this case.

Veligers in this experiment responded to our light/dark regime by migrating vertically. If this were only for the purpose of avoiding UV light, then we would expect, but did not see, similar migration patterns in all 3 populations. Turbidity differences that may be found in the field did not exist under our controlled conditions. Nor could differences among populations be attributed to differences in size (see Gallager et al. 1996), since veligers from all of these populations grew at similar rates. Differences in ZCM among populations might also have resulted from differences in buoyancy or sinking rates (due, for example, to differences in lipid stores or shell weight), which were not measured in this study. However, the fact that the GEO and MB populations differed at only some times of day argues against that explanation.

The induction of vertical migration by differences in food density is also unlikely. Scallop veligers continued to vertically migrate in mesocosms despite a tendency to linger in attractive patches of phytoplankton (SilvaSerra \& O'Dor 1994) and also when food particles were evenly distributed (Gallager et al. 1996, this study). If veligers evolve behavior solely for the purpose of locating food, it makes little sense for them to vacate a profitable patch. Thus, both the idea that patches of veligers result from veligers concentrating where phytoplankton is more dense, and the suggestion that veligers use vertical migration to find better patches of food, are at best partial explanations for their vertical migration. More efficient location of food patches may be one consequence of vertical migration, and veligers do reduce the upward component of their swim paths to remain longer where food is more plentiful (Smyth 1989), but there must be at least 1 other motivation driving vertical migration.

Once veligers are ready to settle they are found throughout the water column. Since veligers must, presumably, settle on or near the bottorn, this distribution pattern may signal that veligers no longer avoid the colder bottom layer of the water column by upward swimming in response to a change in temperature. Even though veligers were found throughout the water column in a previous experiment with a $10^{\circ} \mathrm{C}$ thermocline, they settled preferentially in the upper layers (Pearce et al. 1996). In this experiment, with a much smaller thermocline, veligers showed no differences among the 3 populations: they ignored the thermocline at settlement with number of spat settled increasing slightly with depth (C. M. Pearce unpubl obs.). The ultimate cause of differences in vertical distribution 
among populations was not, therefore, different preferences for depth of settlement.

Subsequent experiments with veligers (using microsatellite DNA markers) in the tower tank have demonstrated that veligers from GEO and PAS have different vertical distributions in the same mesocosm (Manuel et al. 1996), indicating real genetic differences, not mesocosm artifacts. King \& Miracle (1995) reported that different clones of Daphnia longispina have different vertical distributions, evidence for a genetic component in vertical migration in that species. The intense aggregations seen at night, and indeed the migrations observed, are not just an effect of the mesocosms themselves since veligers of another bivalve species (Mytilus trossulus) exhibited very different behavior under the same experimental conditions, remaining within $1 \mathrm{~m}$ of the thermocline at all times (MacQuarrie 1995). Thus we not only see differences in the behaviors observed among different populations of scallop veligers, but even more pronounced differences from behavior of veligers of other bivalve species under the same experimental conditions.

\section{Predation avoidance as ultimate cause of vertical migration in bivalve veligers}

Vertical migration for the purpose of predation avoidance can produce complex responses (see Clark \& Levy 1988). In recent years, there has been considerable support for predator avoidance as the ultimate cause of vertical migration in crustacean zooplankton (reviewed by Lampert 1993). Researchers have found a correlation between predator abundance and the strength of vertical migration (Bollens \& Frost 1989b, Bollens et al. 1992), in marine copepod migration in response to free ranging, but not caged, fish (Bollens \& Frost 1989a), and in fresh water the responses of prey to changes in light intensity are greatly enhanced by just the chemical exudates of a predator (Ringelberg 1991). However, if vertical migration were entirely determined by predation pressure, then one might expect to see individuals of similar size but different species behave in a similar manner, since presumably they would be subject to similar predation pressure. As with the different species of bivalve veligers, Osgood \& Frost (1994) found very few similarities in the behavior of similar-sized individuals of 2 co-occurring species of copepod (Calanus pacificus and Metridia lucens). They also found that vertical distributions and behaviors vary not only between species and among the different developmental stages of each species, but also between dates. This argues for at least 1 other factor in vertical migration besides predation avoidance. While this factor could be related to predation (one species is easily caught or more attractive to the predator), it could as well be argued that another ultimate cause is altering vertical migration behavior

However strong the evidence that predation avoidance may be an ultimate cause of vertical migration in crustacean zooplankton, there are several problems with this explanation for bivalve veligers. Firstly, bivalve veligers are probably unattractive prey, as they are able to close up tightly enough to pass intact through the guts of both vertebrate and invertebrate predators, with only ctenophores posing a serious threat (Mileikovsky 1974, Kane 1984, Purcell et al 1991). Blaxter (1968) has shown that, once ingested, bivalve veligers may actually harm herring larvae (which are present in the same time and place as Placopecten magellanicus veligers) by slowing the passage of material through the gut. Veligers may or may not live after this, but predators have little reason to focus on such unfulfilling food. Secondly, any hypothesis must explain not only the migrations, but the fact that individual zooplankton make those migrations in synchrony with other individuals. Without synchrony distributions alone cannot detect vertical migrations (Pearre 1979). Light intensity should not be the proximal cause of the synchrony of normal (up at night, down during the day) diumal migration of a prey of a non-visual predator such as ctenophores, unless the predator itself exhibits either reversed migration or diurnal variations in feeding intensity. Finally, the size of bivalve veligers $(<300 \mu \mathrm{m})$ also means that their visual predators (e.g. larval fish) are extremely vulnerable prey themselves. Many of the younger stages of crustacean zooplankton, which are larger than the oldest bivalve veligers, do not migrate vertically, and zooplankton subject to predation by small visual predators can be induced to perform reversed (up in the day, down during night), rather than normal vertical migrations (Lampert 1993). Dinoflagellates are a more reasonable model for bivalve veligers, since they also make vertical migrations, are often unpalatable because they contain various noxious substances (which might be compared to the indigestibility of bivalve veligers) and are closer in size to scallop veligers than most planktonic crustaceans. Thus, the role of predation as an ultimate cause of vertical migrations in bivalve veligers is more likely to follow the dinoflagellate than the crustacean model. The most commonly suggested reasons for vertical migrations in dinoflagellates are access to nutrients below stratified layers (which results in reversed vertical migration) and horizontal transport to aid in retention (Anderson \& Stolzenbach 1985).

Even though bivalve veligers are seldom (if ever) recorded as the principle prey of any one species, they are occasionally prey of many larval fish in the appro- 
priate size range. It is therefore difficult to eliminate predation avoidance in explaining the dawn and dusk responses of Placopecten magellanicus veligers. However, it is not necessary to invoke predation avoidance to explain migrations at dawn and dusk, since such migrations can assist horizontal transport (Hill 1994. Manuel 1996). In this experiment, the vertical migration differences that we see among populations, particularly those involving the timing of migrations, seem to result from migrations that occur at times of the day other than at dawn and dusk. If predation avoidance is an ultimate cause of vertical migration in our experiment, then it is more likely to explain the similarities (i.e. the dawn and dusk responses) than the differences among these populations.

\section{Could horizontal transport be one of the ultimate causes of vertical migration in bivalve veligers?}

If intense aggregations of veligers such as observed near the surface in this and a previous (Gallager et al. 1996) experiment occur in nature, then surface events such as wind patterns could potentially have great effect on the horizontal transport of veligers. Two of the populations studied here (PAS and MB) occupy coastal bays, and as such must be subject to local wind events. Since coastal winds usually blow in during the day and out at night, an organism using such surface winds to limit dispersal away from a bay or inlet might be expected to exhibit reverse migration. That neither $\mathrm{MB}$ or PAS veligers exhibited such behavior eliminates this as an explanation for the dawn and dusk response of veligers.

Hill (1994) has shown that diel vertical migration can result in horizontal transport by the tides induced by the sun $\left(S_{2}\right.$ currents) in the open ocean. The direction and speed of transport depend on the local phase (time of the tide relative to local midnight) of the $S_{2}$ currents relative to the time of sunrise and sunset, and such transport may affect the location and species composition of zooplankton aggregations on a large scale. Diel vertical migration also causes transport by moon tide $\left(\mathrm{M}_{2}\right)$ currents, but the direction and speed of transport changes daily, and over a period of $14.8 \mathrm{~d}$, the net result is almost nil because transport in one half of the period cancels the transport in the other half of the cycle (Hill 1991). However, if, for example, a zooplankter were to alternate $7.4 \mathrm{~d}$ periods of vertical migration with 7.4 d periods without vertical migration, net transport would result. In the case of Placopecten magellanicus veligers, differences among these populations are most pronounced at times other than at dawn and dusk, and the $\mathrm{M}_{2}$ currents in all of these populations is much larger than the $S_{2}$ currents. If veligers are using vertical migration for horizontal transport, a promising place to look, therefore, is in migrations that occur other than at dawn and dusk.

After about $21 \mathrm{~d}, \mathrm{MB}$ and GEO veligers begin to make excursions (lasting sometimes only a few hours and always during the day) below the thermocline. Thermoclines often are associated with changes in current velocity and/or direction. Vertical migration in the region of the thermocline can produced horizontal transport if the migration occurs with the same period (or any multiple thereof) as the tide (Hill 1991). If $M B$ and PAS veligers are using tidal $\left(\mathrm{M}_{2}\right)$ currents for transport, the differences between $M B$ and GEO veligers in the timing of descent from the surface at night suggests slightly different strategies. Perhaps the 2 populations are using, or 'expect', a slightly different tidal phase. Both GEO and MB veligers must contend with net transport on a large gyre: in the case of $M B$ the gyre is open on the southwestern side, in the case of GEO circulation around the gyre takes longer than the length of larval life. PAS veligers did not exhibit this behavior at all. Either PAS veligers are using a different strategy, and/or their migration response is triggered by a stimulus different than GEO and MB (for further discussion see Manuel 1996). Note that the largest adult beds are located at the mouth rather than further inside Passamaquoddy Bay (Fig. 1). The tidal ellipse in this region indicates extremely strong movement perpendicular to the mouth of the estuary (eastwest), and very small currents parallel to the estuary (north-south). Tidal transport in the macro tides of the Bay of Fundy (among the largest in the world) could easily move veligers up into the Bay of Fundy rather than into the Passamaquoddy estuary. Thus behavior used by other populations for retention in large gyres may have been selected out of the PAS population.

There may be several selective pressures driving vertical migration, and the most successful strategy must inevitably involve trade-offs among them. In our experience, the diurnal response of veligers (swimming up at dusk and down at dawn) has been relatively consistent, but is markedly reduced in PAS veligers. Although this behavior may assist in predation avoidance, this does not negate the possibility that veligers are gaining horizontal transport from vertical migration. Predation has been known to result in a lunar periodicity in zooplankton abundance (Gliwicz 1986), and selection for behaviors to avoid the 'moontrap' might reasonably be expected to result in the evolution of an internal clock with a lunar period. Such an internal clock could be easily adapted to control vertical migration to take advantage of tidal currents for horizonta] transport (Manuel 1996).

The final test of the retention hypothesis requires a model which links observed behaviors to real hydro- 
graphic movements, which are primarily tidal. In our experiments, veliger movements other than simple diurnal migration do occur, at times obliterating the diurnal effect entirely (e.g. Fig. 6, MB 19 d), and the timing of these other movements relative to the diurnal migration varies considerably. In order to determine whether such migrations have a tidal periodicity, it is necessary to conduct experiments that have a resolution fine enough to reveal movements at least 6 times a day ( 2 diurnal migrations and 4 tidal migrations) and over a time span that covers at least $14.8 \mathrm{~d}$ (the period of the interaction between lunar and sun tides). If some movements occur at a tidal period, then considerable horizontal transport might result. To determine the ultimate causes of vertical migration in Placopecten magellanicus veligers, additional experiments have been conducted to examine theoretically the transport consequences of migrating at both diurnal and tidal periods (see Manuel 1996)

If veliger vertical migration behavior were invariant among population or species, then the location of adults would be a consequence of physical oceanography. Populations would exist only where the interaction of veliger behavior and physical oceanography placed veligers at the right place (over adult beds) at the right time (when the veligers were competent). Permanent beds of vagrant (sensu Sinclair 1988) adults might appear where veligers were consistently 'lost' from another population, but these beds would be dependent on the self-recruiting population for renewal, and would disappear if the self-recruiting population 'upstream' was removed. But since veliger behavior does vary among populations and species, habitats that would otherwise be unavailable are opened up.

If veliger vertical migration behavior commonly varies among populations (remembering that for this experiment we deliberately chose the most varied habitats we could find), this has consequences for both aquaculture and management of wild stocks. Veliger behaviors selected for in the wild because they aid in retention might reduce survival of veligers in the relatively crowded conditions and shallow containers used in hatcheries. It is possible that hardy species under hatchery protocols are those that by chance exhibit behaviors that (at the least) don't harm their survival in small tanks. Hatchery success might be improved by judicious selection of the original population. Adult survival would not predict recruitment success, and veliger behavior should be considered when introducing new animals to a region. Enhancement programs might improve success by using either native stock or a population from an area with physical oceanography similar to that of the target area. Defining 'similar physical oceanography', of course, requires that we understand how retention is achieved by veligers under different conditions. It might even be possible, by selective breeding or by transporting collected juveniles back to adult beds, to place new populations of valuable invertebrates (such as scallops) where none previously existed. The seriousness of the consequences of moving animals, and the success of efforts to use vertical migration behavior constructively, depend on 3 presently unknown factors: the magnitude of the losses incurred by inappropriate behavior, the amount of variation among populations (or species) and the heritability of the behaviors within the population. If heritability is high and losses are low enough so that some veligers manage to make their way back to adult beds, recruitment might be low for a few years, but eventually a successful strategy will evolve. If the opposite is true, then introduced stocks might not only be unsuccessful themselves, but also interfere with native stocks by cross-breeding.

The precise suite of behaviors required for recruiting veligers back to parental beds may be more complex than those outlined here and may involve other stimuli. The most critical observation here is that there is variation in vertical migration behavior among populations. By examining such behavior further, it may be possible to determine whether such differences are ultimately due to the horizontal transport consequences of vertical migration behavior. Future attempts to relate the vertical migrations and distributions of zooplankton to ecological boundaries such as chlorophyll maxima or thermoclines must consider that there may exist differences among populations (and certainly between species) that relate, not to the degree of physical mixing, local ecology or amount of food available, but rather to the retention strategy of the population involved. If the retention strategy involves moon tide transport, behavior will alter in sequential weeks, and sampling regimes must consider this

Acknowledgements. We gratefully acknowledge the support and assistance of Matthew Manuel, who turned video taped images into reams of data sets; Danny Jackson, who kept the computers running; Donna Krailo, who grew the algae. Financial support was provided to J.L.M. by the Natural Sciences and Engineering Research Council of Canada, and to R.K.O'D. from OPEN and IFRP. We also thank Sifford Pearre, who gave an insightful review of an earlier draft, and 4 anonymous reviewers. This is a contribution to the program of OPEN (Ocean Production Enhancement Network, one of the 15 Networks of Centres of Excellence supported by the Government of Canada) and IFRP (Interim Funding Research Program).

\section{LITERATURE CITED}

Ambrose WG Jr, Peterson CH, Summerson HC, Lin J (1992) Experimental tests of factors affecting recruitment of bay 
scallops (Argopecten irradians) to spat collectors Aquaculture 108:67-86

Anderson DM, Stolzenbach KD (1985) Selective retention of two dinoflagellates in a well-mixed estuarine embayment: the importance of diel vertical migration and surface avoidance. Mar Ecol Prog Ser 25:39-50

Angel MV (1985) Vertical migrations in the oceanic realm: possible causes and probable effects. In: Rankin MA (ed) Migration: mechanisms and adaptive significance. The Univ of Texas at Austin, Port Arkansas, TX, p 45-70

Balch N. Boyd CM. Mullin M (1978) Large-scale tower tank systems. Rapp PV Réun Cons Int Explor Mer 173:13-21

Beaumont AR, Zouros E (1991) Genetics of scallops. In Shumway SE (ed) Scallops: biology, ecology and aquaculture. Elsvier, Amsterdam. p 585-623

Blaxter JHS (1968) The effect of light intensity on the feeding ecology of herring. In: Bainbridge R, Evans GC, Rackham $O$ (eds) Light as an ecological factor Brit Ecol Soc Symp (6). John Wiley and Sons Inc., New York, p 393-409

Bollens SM, Frost BW (1989a) Predator-induced diel vertical migration in a planktonic copepod. J Plankton Res 11: $1047-1065$

Bollens SM, Frost BW (1989b) Zooplanktivorous fish and variable diel vertical migration in the marine planktonic copepod Calanus pacificus. Limnol Oceanogr 34:1072-1083

Bollens SM, Frost BW, Thorenson DS, Watts SJ (1992) Diel vertical migration in zooplankton: field evidence in support of the predator avoidance hypothesis. Hydrobiologia 234:33-39

Bumpus DF (1976) Review of the physical oceanography of Georges Bank. ICNAF Res Bull 12:119-134

Clark CW, Levy DA (1988) Diel vertical migrations by juvenile sockeye salmon and the antipredation window. Am Nat 131:271-290

Collins TM (1989) A comparative study of zooplankton in the field and laboratory. MSc thesis, Dalhousie Univ, Halifax, Nova Scotia

Cragg SM (1980) Swimming behaviour of the larvae of Pecten maximus (L.) (Bivalvia). J Mar Biol Ass UK 60:551-564

Culliney JL (1974) Larval development of the giant scallop Placopecten magellanicus (Gmelin). Biol Bull Mar Biol Lab, Woods Hole 147:321-332

Dadswell MJ (1993) Reproduction and recruitment dynamics of sea scallop (Placopecten magellanicus) in the Canadian Maritimes. In: Bourne NF, Bunting BL, Townsend LD (eds) Proceedings of the 9th international pectinid workshop, Nanaimo, BC, Canada, April 22-27, 1993. Can Tech Rep Fish Aquat Sci 1:1.47

Dadswell MJ, Parsons GJ (1992) Exploiting the life-history characteristics of the sea scallop, Placopecten magellanicus (Gmelin, 1791), from different geographical locations in the Canadian Maritimes to enhance suspended culture grow-out. J Shellfish Res 11:299-305

Damkaer DM (1982) Possible influences of solar UV radiation in the evolution of marne zooplankton. In: Calkins J (ed) The role of solar ultraviolet radiation in marine ecosystems. Plenum Press, New York, p 701-706

Dibacco C, Robert G, Grant J (1995) Reproductive cycle of the sea scallop, Placopecten magellanicus (Gmelin, 1791), on northeastern Georges Bank. J Shellfish Res 14:59-69

Din SHSE, Hassan EM. Trites RW (1970) The physical oceanography of St. Margaret's Bay. Fish Res Bd Can Tech Rep 219:1-222

Enright JI (1977) Diurnal vertical migration: adaptive significance and timing. Part I. Selective advantage: a metabolic model. Limnol Oceanogr 22:856-872

Enright JT, Hamner WM (1967) Vertical diurnal migration and endogenous rhythmicity. Science 157:937-941

Fevolden SE (1989) Genetic differentiation of Icelandıc scallop Chlamys islandica (Pectinidae) in the northern Atlantic ocean. Mar Ecol Prog Ser 51:77-85

Flagg CN (1987) Hydrographic structure and variablity. In: Backus RH, Bourns DW (eds) Georges Bank. MIT Press, Cambridge, MA, p 108-124

Forward RB Jr (1988) Diel vertical migration: zooplankton photobiology and behaviour. Oceanogr Mar Biol A Rev 26 : $361-393$

Gallager SM (1988) Visual observations of particle manipulation dunng feeding in larvae of bivalve molluscs. Bull Mar Sci 43:344-365

Gallager SM, Manuel JL, Manning DA, O'Dor R (1996) The vertical distribution of scallop larvae Placopecten magellanicus in $9 \mathrm{~m}$ deep mesocosms as a function of light, food. and temperature. Part I. Ontogeny of vertical migration behavior. Mar Biol 124:679-692

Gamble JC, Davies JM (1982) Application of enclosures to the study of marine pelagic systems. In: Grice GD, Reeve MR (eds) Marine mesocosms. Springer-Verlag, New York, p $25-48$

Gliwicz ZM (1986) Predation and the evolution of vertical migration in zooplankton. Nature (Lond) 320:746-748

Hardy AC, Gunther E (1935) The plankton of the South Georgia whaling ground and adjacent waters, 1926-27 Discovery Rep 11:1-456

Hill AE (1991) Vertical migration in tidal currents. Mar Ecol Prog Ser 75:39-54

Hill AE (1994) Horizontal zooplankton dispersal by diel vertical migration in $S_{2}$ tidal currents on the northwest European continental shelf. Cont Shelf Res 14:491-506

Huntley M (1985) Experimental approaches to the study of vertical migration of zooplankton. In: Rankin MA (ed) Migration: mechanisms and adaptive significance. The Univ of Texas at Austin, Port Arkansas, TX, p 71-90

Kane $J$ (1984) The feeding habits of co-occurring cod and haddock larvae from Georges Bank. Mar Ecol Prog Ser 16: 9-20

Kimmerer WJ, McKinnon AD (1987) Zooplankton in a marine bay. I. Vertical migration to maintain horizontal distributions. Mar Ecol Prog Ser 41:53-60

King CE, Miracle MR (1995) Diel vertical migration by Daphnia longispina in a Spanish lake: genetic sources of distributional vanation. Limnol Oceanogr 40:226-231

Lampert W (1993) Ultimate causes of diel vertical migration of zooplankton: new evidence for the predation-avoidance hypothesis. Arch Hydrobiol Beih 38:79-88

Lewis RI, Thorpe JP (1994) Temporal stability of gene frequencies within genetically heterogeneous populations of the queen scallop Aequipecten (Chlamys) opercularis (L.). Mar Biol 121.117-126

Loder JW, Ross CK, Smith PC (1988) A space- and time-scale characterization of circulation and mixing over submarine banks. with application to the northwestern Allantic continental shelf. Can J Fish Aquat Sci 45:1860-1885

Lynch DR, Namie CE (1993) The $M_{2}$ tide and lts residual on the outer banks of the Gulf of Maine. J Phys Oceanogr 23: $2223-2253$

MacQuarrie SP (1995) The vertical cistribution and depth of settlement of mussel larvae, Mytilus trossulus, in $8.5 \mathrm{~m}$ deep mesocosms under controlled conditions. Hon. thesis, Dalhousie University, Halıfax

Manuel JL (1996) Population and temporal variations in the vertical migrations of scallop (Placopecten magellanicus) veligers. PhD thesis, Dalhousie University, Halifax

Manuel JL, Burbridge S, Kenchington EL, Ball M, O'Dor RK 
(1996) Veligers from two populations of scallop (Placopecten magellanicus) exhibit different vertical distributions in the same mesocosm. J Shellfish Res 15:251-257

Manuel JL, Dadswell MJ (1990) Swimming behavior of juvenile giant scallop. Placopecten magellanicus, in relation to size and temperature. Can J Zool 69:2250-2254

Manuel JL, Dadswell MJ (1993) Swimming of juvenile sea scallops, Placopecten magellanicus (Gmelin): a minimum size for effective swimming? J Exp Mar Biol Ecol 174 $137-175$

McLaren IA (1963) Effects of temperature on growth of zooplankton, and the adaptive value of vertical migration. J Fish Res Bd Can 20:685-727

Mileikovsky SA (1974) On predation of pelagic larvae and early juveniles of marine bottom invertebrates by adult benthic invertebrates and their passing alive through their predators. Mar Biol 26:303-311

Orensanz JM, Parma AM, lribarne OO (1991) Population dynamics and management of natural stocks. In: Shumway SE (ed) Scallops: biology, ecology and aquaculture. Elsevier, Amsterdam, p 625-713

Osgood KE, Frost BW (1994) Ontogenetic diel vertical migration behaviors of the marine planktonic copepods Calanus pacificus and Metridia lucens. Mar Ecol Prog Ser 104: $13-25$

Pearce CM, Gallager SM, Manuel JM, Manning DA, O'Dor RK (1996) Settlement of larvae of the giant scallop (Placopecten magellanicus) in $9 \mathrm{~m}$ deep mesocosms as a function of temperature stratification, depth, food, and substratum. Mar Biol 124:693-706

Pearre S Jr (1979) Problems of detection and interpretation of vertical migration. J Plankton Res 1:29-44

Purcell JE, Cresswell FP, Cargo DG, Kennedy VS (1991) Differential ingestion and digestion of bivalve larvae by the scyphozoan Chrysaora quinquecirrha and the ctenophore Mnemiopsis leidyi. Biol Bull 180:103-111

Ringelberg J (1991) Enhancement of the phototactic reaction in Daphnia hyalina by a chemical mediated by juvenile perch (Perca fluviatilis). J Plankton Res 13:17-25

Robinson SMC, Martin JD, Chandler RA, Parsons GJ, Couturier CY (1992) Larval settlement patterns of the giant scallop (Placopecten magellanicus) in Passamaquoddy Bay, New Brunswick. CAFSAC Res Doc 92/115, Department of Fisheries and Oceans, Dartmouth, NS

This article was presented by G. C. Harding (Senior Editorial Advisor), Dartmouth, Nova Scotia, Canada
Rogers H (1940) Occurrence and retention of plankton within the estuary. J Fish Res Bd Can 5:164-171

Scheltema RS (1986) On dispersal and planktonic larvae of benthic invertebrates: an eclectic overview and summary of problems. Bull Mar Sci 39:290-322

Siebeck O (1978) UV-Toleranz und Photoreaktivierung bei Daphnien aus Biotopen verschiedener Höhenregionen. Naturwissenschaften 65:390

Silva-Serra MA, O'Dor RK (1994) Early life history traits of sea scallops, Placopecten magellanicus, from the Georges Bank population: vertical distribution of larvae. In: Bourne NF, Bunting BL, Townsend LD (eds) Proceedings of the 9th international pectinid workshop, Nanaimo, BC, Canada, April 22-27, 1993. Can Tech Rep Fish Aquat Sci 1:67-75

Sinclair M (1988) Marine populations: an essay on population regulation and speciation. Department of Fisheries and Oceans, Dartmouth, NS

Smyth C (1989) A foraging strategy of (D-stage) Placopecten magellanicus larvae: observed differences in swimming pattern in the presence and the absence of the algae Isochrysis galbana. Hon thesis, Dalhousie University, Halifax

Sokal RR, Rohlf J (1981) Biometry: the principles and practice of statistics in biological research. WH Freeman, San Francisco

Tremblay JT (1991) Sea scallop larvae Placopecten magellanicus in the Georges Bank region: distribution, abundance and condition. PhD thesis, Dalhousie University, Halifax

Tremblay MJ, Loder JW, Werner FE, Naime CE, Page FH, Sinclair MM (1994) Drift of sea scallop larvae Placopecten magellanicus on Georges Bank: a model study of the roles of mean advection, larval behavior and larval origin. Deep Sea Res 41:7-49

Tremblay MJ, Sinclair M (1990a) Sea scallop larvae Placopecten magellanicus on Georges Bank: vertical distribution in relation to water column stratification and food. Mar Ecol Prog Ser 61:19-25

Tremblay MJ, Sinclair M (1990b) Diel vertical migration of sea scallop larvae in a shallow embayment. Mar Ecol Prog Ser 67:19-25

Trites RW, Garrett CJR (1983) Physical oceanography of the Quoddy region. In: Thomas MLH (ed) Marine and coastal systems of the Quoddy region, New Brunswick. Can Spec Publ Fish Aquat Sci 64:9-33

Manuscript first received: July 25, 1995

Revised version accepted: July 22, 1996 